\title{
Major factors contributing to the construction waste generation in building projects of Iraq
}

\author{
Tareq Khaleel $^{1}$, and Ahmed Al-Zubaidy ${ }^{1, *}$ \\ ${ }^{1}$ Building and Construction Engineering Department, University of Technology, Baghdad, Iraq
}

\begin{abstract}
Due to the economic growth and improvement of the construction industry witnessed by most countries, there has become a crucial need for employing modern possibilities in the construction sector to build taller, longer and deeper structures. However, one aspect that heads forward with the same intensity is the generation of 100 million tons of construction waste every year. This generation has occurred due to several factors with different levels of importance. Hence, this study reveals 15 factors influencing construction waste generation and categorizes them into 3 groups, (materials management on site), (materials handling, transportation and storage) and (site management and practices). A questionnaire survey of 100 respondents was distributed among different engineers to assess the construction waste factors. Results showed that damage of materials on site, double handling of materials and incompetent contractor's technical staff were the most significant factors of each category with Relative Importance Indexes (RII) of $0.866,0.844$ and 0.83 , respectively. These findings will help the practitioners to reduce construction waste quantities in sites and improve waste management performance factors to control the construction waste problems.
\end{abstract}

\section{Introduction}

The construction industry has a dynamic function in most developing countries. Currently, it is facing many barriers and issues associated with unbelievable quantities generated from construction waste. Undoubtedly, the improvement in the standard of livings, changes in consumption behaviors as well as the natural growth in population lead to increase the amount of construction waste, which is demonstrated significantly in the past two decades [1]. Quantification of construction waste generated from different construction activities was being the first priority of most environmental agencies. To show that, United States Environmental Protection Agency (EPA) has revealed that 170 million tons of construction waste were generated in 2002 [2].

As a developing country, Iraq is confronted with the construction waste problem which has resulted in illegal dumping that adds to environmental pollution and, furthermore, increases the project cost. This problem can worsen if not addressed properly. Design, materials handling, transportation and storage are major contributory activities in generation of construction waste [3]. Such activities would deplete time and energy without adding value to the client, thus, resulting in wastage of construction materials, delay in meeting the specified time and execution of useless activities. Finding out the root cause of construction waste is an effective way to avoid it.
In this context, this research is meant to reveal most frequent construction waste factors of common categories, collected from several methodological approaches that influence the construction waste generation. Furthermore, evaluating those factors using statistical measurements to identify the priority and impact of each factor in order to reduce the project cost deviation and thus, increase the project profits.

\section{Problem statement}

It is observed that the quantities of construction waste are growing rapidly due to the fact that there is an intensive rise in the number of construction projects throughout the world, especially nationwide. The rates of construction waste materials in most projects in Iraq have already exceeded the permissible limits set by the Iraqi Ministry of Construction \& Housing (MOCH). Green Middle East in 2007 stated that "Gulf Cooperation Council (GCC) countries produce nearly 80 million tons of waste annually" [4]. This indicates that the generation of construction waste, at this region, is rising expeditiously. Therefore, would motivate the experts for crucial necessity to develop an effective waste management system in sites as soon as possible. Furthermore, would motivate to identify the influencing factors which contribute to increase the construction waste quantities. 


\section{Literature review}

\subsection{Concept of construction waste}

Experts in the construction sector have believed, for long decades, that there is a direct relationship with only the debris disposed from project site and the construction waste produced from different construction activities [5]. Hence, some researchers have defined the waste produced from construction activities, in terms of mathematical analysis, as "the difference between the value of materials delivered and accepted on site, and materials used properly as specified and accurately measured in the work" [6].

Nowadays, waste is defined by means of lean production philosophies as "any inefficiency that results in the use of equipment, materials, labor or capital in larger quantities than those considered as necessary in the production of a building" [7]. Another research work defined waste as "any loss produced by activities that generate direct or indirect costs but do not add any value to the product from the point of view of the client" [8]. In virtual works, some studies reported, through seven sites, that labors consume nearly $46 \%$ of working time for the value-adding activities, whereas the remaining majority consumed for non-value adding activities [9]. Other proved even worse conclusions that only from 3 to $20 \%$ of steps add-value, and their share of the whole cycle time ignored from 0.5 to $5 \%$ [10]. Hence, minimizations of non-value adding activities provide an extensive potential improvement in most operational processes. Besides a clear understanding of the construction waste concept, it is necessary to identify the classification of waste in different perspectives.

\subsection{Classification of construction waste}

Construction waste can be classified into two different categories, namely physical waste and non-physical waste.

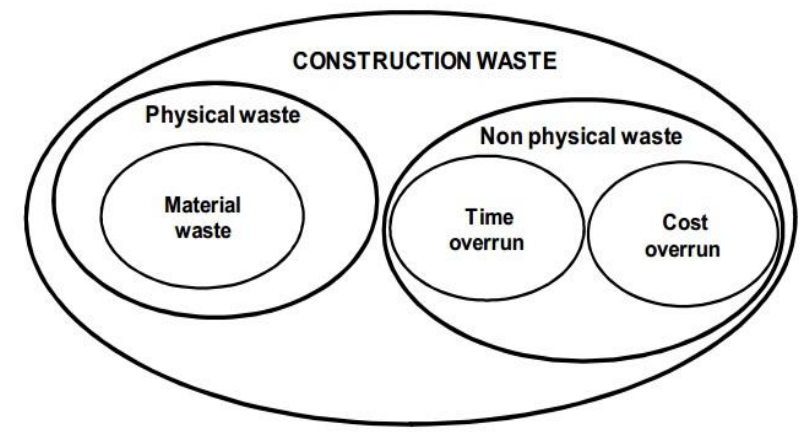

Fig.1. Construction waste classification [11]

\subsubsection{Physical Waste}

Physical construction waste is denoted as "the waste which originates from construction, renovation and demolition actions including land excavation, civil and building construction, site clearance, roadwork, and building demolition and renovation" [12-15]. In other words, physical waste is recognized as the debris which can be observed at any construction project. It involves exhaustion of construction materials, since they are irreparably damaged or simply lost. The wastage is usually removed from the construction site to landfills. However, physical waste is classified into three subdivisions: additional material loss, man-hour overproduction and equipment operational time.

\subsubsection{Non-physical Waste}

On the contrary, both time and cost overrun are the major forms of non-physical waste which is commonly developed during construction process. Waiting durations, work interruptions, delays in execution and obtaining work permits, reworks and performance of unnecessary works are forms of time wastages [7,8], whereas, cost overrun, which is also referred as "cost increase" or "budget overrun", involves unanticipated costs incurred in excess of the budgeted amounts [16]. Several researchers have reported that both time and cost wastes may cause of material waste generation. For instance, Memon et.al stated that "non-physical waste includes undesired activities, which can cause the physical waste, such as rework, and unnecessary material movements" [17].

\subsection{Construction waste generation}

The construction waste generation has created serious problems, both locally and globally. Construction waste materials are generated when new buildings are built. Buildings include all residential and non-residential structures, as well as public works projects, such as roads, bridges and dams [18]. In 2002, the United Kingdom (UK) generated 200 million tons of total waste. $50 \%$ of this quantity was generated by construction, demolition, renovation and refurbishment works. $24 \%$ generated in commercial and industrial activities, with households responsible for a further $14 \%$ [19], Whereas EPA, which is located in the United States (US), stated that "approximately 136 million tons of construction waste was generated in 1998 [20], and it raised to 170 million tons in 2003[21]".

The Arab gulf region is facing a serious challenge associated with inadequate management of construction waste, where most countries have the highest per capita waste generation in the world. Industrial growth, changing lifestyles, construction strategies, unsustainable consumption patterns and rapid urbanization have all contributed to the growing of waste problem. Green Middle East in 2007 stated that (GCC) countries produce nearly 80 million tons of waste annually; half of this consists of construction material wastage, and approximately $33 \%$ is municipal solid waste while the rest is industrial waste [4]. Others estimate the solid waste quantities in (GCC) at around 120 million tons per 
year [22]. Hence, the scale of the challenge faced by waste management sectors in the Arab gulf region is even larger. It is obvious that these rates are growing rapidly and create a serious problem which threaten the socio-economy of countries. Therefore; an immediate development of waste management approaches is being a crucial necessity in this region.

\subsection{Causes of construction waste generation}

Among various researches published around the world about construction waste generation and its management, only a few studies can be identified as those that are focused on revealing the factors contributing to construction waste generation. Researchers that covered construction waste generation detected a number of construction waste sources that may rise during the life cycle of a project.

The construction management performance factors are described as the actions which decrease construction waste quantities and contribute to increase recycling at the construction sites. Hence, with the concept of the possibility of decreasing construction waste, several factors were collected through interviews and extensive literature reviews. Subsequently, it was discovered that several factors would have influence on construction waste generation. Thus, 15 factors were categorized by common characteristics: "Materials Management OnSite", "Materials Handling, Transportation and Storage" and "Site Management and Practices". Table (1) lists these 15 factors by categories.

Table 1. Construction waste sources

\begin{tabular}{|c|c|c|}
\hline \multicolumn{2}{|c|}{ Category } & Factor \\
\hline \multirow{6}{*}{ 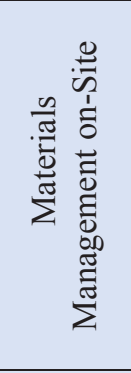 } & 1.1 & Damage of materials on site \\
\hline & 1.2 & Manufacturing defects \\
\hline & 1.3 & Packaging defects \\
\hline & 1.4 & Theft and vandalism \\
\hline & 1.5 & $\begin{array}{l}\text { Inadequate control on construction } \\
\text { materials in site }\end{array}$ \\
\hline & 1.6 & $\begin{array}{l}\text { Oversized of building elements } \\
\text { during execution due to non- } \\
\text { straightness of construction works }\end{array}$ \\
\hline \multirow{5}{*}{ 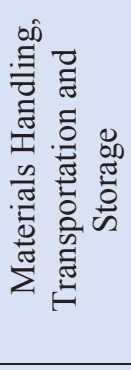 } & 2.1 & Wrong handling of materials \\
\hline & 2.2 & $\begin{array}{l}\text { Materials storage away from the } \\
\text { work site and wastage during } \\
\text { transportation }\end{array}$ \\
\hline & 2.3 & $\begin{array}{l}\text { Poor and wrong storage of } \\
\text { materials }\end{array}$ \\
\hline & 2.4 & Double handling of materials \\
\hline & 2.5 & $\begin{array}{l}\text { Accidents during handling and } \\
\text { transportation }\end{array}$ \\
\hline \multirow{3}{*}{ 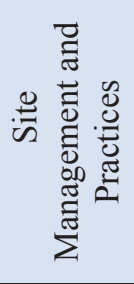 } & 3.1 & $\begin{array}{l}\text { Lack of responsibility of waste } \\
\text { management by the resident } \\
\text { engineer }\end{array}$ \\
\hline & 3.2 & $\begin{array}{l}\text { Absence or weakness of waste } \\
\text { management plan }\end{array}$ \\
\hline & 3.3 & $\begin{array}{l}\text { Incompetent contractor's technical } \\
\text { staff }\end{array}$ \\
\hline
\end{tabular}

3.4 Lack of positive incentive that aims to waste reduction

As mentioned above, these 15 factors indicate the elements which may contribute to decreasing waste quantities at the construction site. As such, if a construction site is assessed based on these 15 factors in terms of execution level of the site, it is possible to assess the performance level of the project. However, since all the factors do not have the same level of importance, it is necessary to determine the magnitude of importance of all the identified factors.

\section{Methodology}

\subsection{Questionnaire design}

A structured questionnaire consists of two sections: the first section describes the demographic data sample of the participated respondents, while the other section identifies the 15 factors that contribute to construction waste generation which have been categorized into 3 groups as shown in Table (1). Then, the respondents were requested to evaluate the potential causes of construction waste by assigning score to each factor wherever observed. The questionnaire measured on a 5point Likert scale where 1 represents "Ineffective", 2 is "Somewhat Effective", 3 is "Moderately Effective", 4 is "Effective" and 5 is "Very Effective".

\subsection{Data collection}

The Center for Strategy Research recommends that the minimum sample size of a questionnaire survey to accurately estimate the reality is 30 respondents or more [23]. Thus, a total of 100 respondents were elected in this study from different engineers who have different years of experience; 42 respondents included were collected via web and the rest were collected via form. There is a crucial necessity for testing the reliability of results when dealing with questionnaire survey. Hence, Cronbach's Alpha is the most commonly statistical measurement used to estimate the reliability of questionnaire provided with Likert scale. Table (2) illustrates some of descriptive statistics with Cronbach's Alpha of the data sample.

Table 2. Statistical analysis of data sample

\begin{tabular}{|c|c|}
\hline Statistic Function & Value \\
\hline $\mathrm{N}$ & 100 \\
\hline Minimum & 3.11 \\
\hline Maximum & 4.33 \\
\hline Median & 4.02 \\
\hline Mean & 3.92 \\
\hline Standard Deviation & 0.33 \\
\hline Cronbach's Alpha & 0.848 \\
\hline
\end{tabular}


It is observed that Cronbach's Alpha coefficient is 0.848, which rule of thumb considers it as a good indication when it normally lies between 0.8-0.9.

\subsection{Data analysis}

The analysis was aided using Statistical Package for Social Sciences (SPSS) software V24. The rates, linked up with each factor, were exposed for further statistical analysis for the purpose of identifying the priority and the importance of the contributory factors by use of Relative Importance Index (RII). The value of RII mainly lies between ( 0 to 1$)$, the higher the better. Equation (1) describes the computational method to calculate the RII for each factor separately, whereas Tables (4) to (6) show the analysis results.

$$
R I I=\frac{\sum W}{A * N}
$$

Where:

$W$ : is the attached score of each factor and mainly ranges between ( 1 to 5 ), (where " 1 " is "ineffective" and "5" is "very effective");

$A$ : is the highest score (i.e. 5 in this study) and; $N$ : is the sample size of the questionnaire (i.e. 100 in this study).

\section{Results and discussion}

\subsection{Respondent's profile}

The sample frame for this study consisted of architects, civil, electrical and mechanical engineers who deal with the construction waste directly at the construction site. The purpose of the respondent's profile diverse is to obtain more opinions about construction waste factors from different perspectives. Table (3) represents the demographic data of this study.

Table 3. Demographic Data of the Study

\begin{tabular}{|c|c|}
\hline $\begin{array}{l}\text { Respondent's } \\
\text { Characteristics }\end{array}$ & Percentage $(\%)$ \\
\hline \multicolumn{2}{|c|}{ Engineering Specialization } \\
\hline Civil & 81 \\
\hline Architect & 9 \\
\hline Electrical & 1 \\
\hline Mechanical & 9 \\
\hline \multicolumn{2}{|c|}{ Academic Qualification } \\
\hline B.Sc. & 62 \\
\hline Higher Diploma & 1 \\
\hline M.Sc. & 17 \\
\hline Ph.D. & 20 \\
\hline \multicolumn{2}{|c|}{ Work Field } \\
\hline Academic & 16 \\
\hline Site & 66 \\
\hline Both & 18 \\
\hline \multicolumn{2}{|c|}{ Years of Experience } \\
\hline $1-7$ & 15 \\
\hline
\end{tabular}

\begin{tabular}{|l|l|}
\hline $8-14$ & 23 \\
\hline $15-21$ & 22 \\
\hline $22-28$ & 11 \\
\hline $9-35$ & 15 \\
\hline More than 35 & 14 \\
\hline
\end{tabular}

\subsection{Construction waste factors}

After analyzing the respondent's profile, it is necessary to analyze the score of the factors concerned at which ranked by respondents. The concerned factors were categorized under 3 different groups as follows:

\subsubsection{Materials management on-site factors}

Damage of materials on site is realized to be the highest influential waste factor of materials management category with RII of 0.866 . This is obvious, especially in Iraq due to non-compliance with standard storage conditions which have a direct relation to material inventory. Inadequate control on construction materials at site is rated to be the second highest influential waste factor in this group with RII of 0.846 and may occur as a result of engineer's inexperience. Some engineers may ignore or may not take the topicality of construction works or activities seriously such as road leveling before casting, concrete forms and vertical columns straightness, etc. Perhaps those reasons may be one causes of waste generation which is related to the oversize of building elements during execution due to non- straightness of construction works with RII of 0.804 .

Theft and vandalism is ranked fourth with RII of 0.798. The influence of this factor could be by employing a guard at the site and building a steel fence (BRC steel) surrounding the construction site. Both packaging and manufacturing defects have occupied the last ranking with RII of 0.738 and 0.712 , respectively. Table (4) summarizes the RII and rank of material management on site group.

Table 4. Materials management related factors

\begin{tabular}{|c|l|c|c|}
\hline No & \multicolumn{1}{|c|}{ Factor } & RII & Rank \\
\hline 1 & Damage of materials on site & 0.866 & 1 \\
\hline 2 & Manufacturing defects & 0.712 & 6 \\
\hline 3 & Packaging defects & 0.738 & 5 \\
\hline 4 & Theft and vandalism & 0.798 & 4 \\
\hline 5 & $\begin{array}{l}\text { Inadequate control on } \\
\text { construction materials in site }\end{array}$ & 0.846 & 2 \\
\hline 6 & $\begin{array}{l}\text { Oversized of building } \\
\text { elements during execution } \\
\text { due to non- straightness of } \\
\text { construction works }\end{array}$ & 0.804 & 3 \\
\hline
\end{tabular}

5.2.2 Materials handling, transportation and storage factors 
Respondents who assessed the factors, have considered that double handling of materials factor to be the most important factor in this group with highest RII of 0.844 . When the storage is far away from the construction site, the probability of generating waste increases. Therefore, wastage during transportation has been ranked as the second position with RII of 0.832 . Inadequate stacking or insufficient / wrong storage is ranked as the third position with RII of 0.822 . Thus, the storekeeper must comply the standards of the factory, which is related to material storage instructions, in order to minimize wastage resulted from this factor Wrong handling of material is ranked as the fourth factor with RII of 0.718 . Due to weak probability of accidents during handling and transportation, it makes sense to be as the last factor would affect on wastage with RII of 0.622 . Table (5) represents the RII and rank of material handling, transportation and storage category.

Table 5. Materials handling, transportation and storage related factors

\begin{tabular}{|c|l|c|c|}
\hline No & \multicolumn{1}{|c|}{ Factor } & RII & Rank \\
\hline 1 & $\begin{array}{l}\text { Wrong handling of } \\
\text { materials }\end{array}$ & 0.718 & 4 \\
\hline 2 & $\begin{array}{l}\text { Materials storage } \\
\text { away from the work } \\
\text { site and wastage } \\
\text { during } \\
\text { transportation }\end{array}$ & 0.832 & 2 \\
\hline 3 & $\begin{array}{l}\text { Poor and wrong } \\
\text { storage of materials }\end{array}$ & 0.822 & 3 \\
\hline 4 & $\begin{array}{l}\text { Double handling of } \\
\text { materials }\end{array}$ & 0.844 & 1 \\
\hline 5 & $\begin{array}{l}\text { Accidents during } \\
\text { handling and } \\
\text { transportation }\end{array}$ & 0.622 & 5 \\
\hline
\end{tabular}

\subsubsection{Site management and practices factors}

Contractor's incompetent technical staff is intended to be the most dominant factor in site management category with RII of 0.83 as shown in Table (6). To reduce waste, waste management plan should be developed. Hence, the absence or weakness of waste management plan is ranked as the second position with RII of 0.818 , which may occur due to the lack of responsibility on waste management by resident engineer with RII 0.758 . Because of engineers' negligence about construction waste management, the incentive schemes will be discarded by them, which is a convincible matter by ranking it as the last factor with RII of 0.756 .
Table 6. Site management and practices related factors

\begin{tabular}{|c|l|c|c|}
\hline No & \multicolumn{1}{|c|}{ Factor } & RII & Rank \\
\hline 1 & $\begin{array}{l}\text { Lack of responsibility on the } \\
\text { waste management by the } \\
\text { resident engineer }\end{array}$ & 0.758 & 3 \\
\hline 2 & $\begin{array}{l}\text { Absence or weakness of } \\
\text { waste management plan }\end{array}$ & 0.818 & 2 \\
\hline 3 & $\begin{array}{l}\text { Contractor's incompetent } \\
\text { technical staff }\end{array}$ & 0.83 & 1 \\
\hline 4 & $\begin{array}{l}\text { Lack of positive incentive } \\
\text { that aims to waste reduction }\end{array}$ & 0.756 & 4 \\
\hline
\end{tabular}

To sum up, Figure (2) illustrates the identified factors with their importance level and priority as a total percentage in a pie chart where the graph legend has been listed from Table (1).

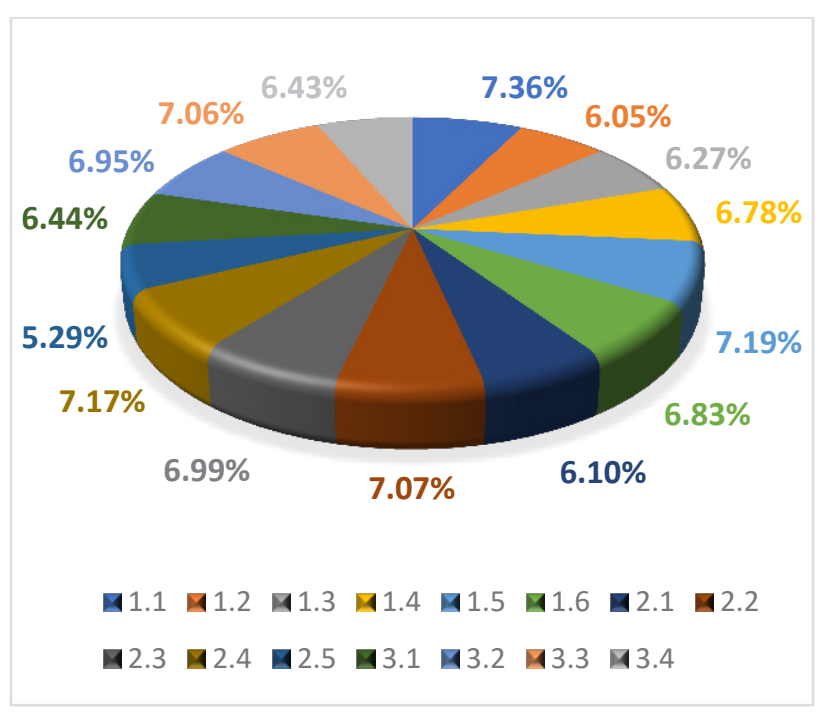

Fig. 2. Construction waste priority factors

\section{Conclusions}

The construction industry is a major element in worldwide economy. As the construction industry increases, the construction waste increases too with the same growing intensity. Least priority in waste minimization and management systems in Iraq leads to generation of huge amounts of construction material waste annually. Illegal landfill disposal, project cost deviation are major problems affecting Iraqi construction sector, which are closely related to construction waste. Fifteen factors have been identified and were considered as mainly responsible for construction waste generation through different project stages with different levels of importance. 


\section{References}

1. A. Katz and H. Baum, Waste Management, 31, 353-358, (2011).

2. H. Yuan, Waste Management, 32, 1218-1228, (2012).

3. L. Ekanayake and G. Ofori, in 2nd Southern African Conference of Strategies for a Sustainable Built Environment, (2000).

4. Green Middle-east, Solid Waste - Solid Growth Prospects", 2017. [Online]. Available: http://www.greenmiddleeast.com/sw/default.ht ml. [Accessed: 07- Apr- 2017].

5. C. Formoso, L. Soibelman, C. De Cesare and E. Isatto, Construction Engineering and Management, 128, 316-325, (2002).

6. L. Pheng and S. Tan, Construction Management and Economics, 16, 621-635, (1998).

7. L. Koskela, Stanford, California, California, USA, (1992).

8. C. Formoso, E. Issato and E. Hirota, in Method for waste control in the building industry, (1999).

9. J. Christian and D. Hachey, Construction Engineering and Management, 121, 20-26, (1995).

10. Ciampa, D., Timebased Competition, Blackburn (Ed.), Business One Irwin, Homewood, IL, 273-293, (1991).

11. S. Nagapan et.al., Faculty of Civil and Environmental Engineering (FKAAS) Digest, 1, 15-20, (2012).

12. O. Kofoworola and S. Gheewala, Waste Management, 29, 731-738, (2009).

13. L. Shen, V. Tam, C. Tam and D. Drew, Construction Engineering and Management, 130, 472-481, (2004).

14. C. Poon, Waste Management, 27, 1715-1716, (2007).

15. V. Tam and C. Tam, Building Research \& Information, 36, 37-43, (2008).

16. Shanmugapriya, S. \& Subramanian, K., International Journal of Emerging Technology and Advanced Engineering, 3, 734-740, (2013).

17. Memon, A.H. Abdul-Rahman, I. and Memon, I., Life Science Journal, 11, 417-424, (2014).

18. M. Abdelhamid, HBRC Journal, 10, 317-326, (2014).

19. Department for environmental Food \& Rural Affairs, (2012).

20. US Environmental Protection Agency (EPA). Prepared by Franklin Associates. (1998), Available from: http://www.epa.gov/epaoswer/hazwaste/sqg/c\& drpt.pdf.

21. US Environmental Protection Agency (EPA), 2003.

[Online].

Available: http://www.epa.gov/epawaste/conserve/rrr/imr/ $\mathrm{cdm} /$ pubs/cd-meas.pdf. [Accessed 15-Apr2017].

22. V. Gautam, South Asia \& Middle East, Environmental \& Building Technologies Practice, (2009), Source: www.frost.com

23. Center for Strategy Research, Inc. Sample Size...How Much is Enough?, (2006), available athttp://www.csrbos.com/Center_for_Strategy_Research_New/T wist/2006_07_Twist.html. 